\title{
Pengaruh Inovasi Dan Pengambilan Risiko Terhadap Perkembangan Wirausaha Muda Dalam Bidang Kuliner Di Wilayah Binong Tangerang
}

\author{
Juliana \\ Fakultas Pariwisata, Universitas Pelita Harapan \\ Email : Juliana.stpph@uph.edu
}

\begin{abstract}
This research was conducted to find out whether there is a significant influence between the variables of innovation and risk taking on the development of young entrepreneurs who run their businesses in the culinary field in the Binong area of Tangerang. The population of this study is young entrepreneurs in the culinary field in the Binong area of Tangerang. The sampling method is done by purposive sampling technique. The method of data collection is done by questionnaire method by giving questionnaires to 50 respondents. All data analysis techniques use the IBM SPSS Statistics 22 program. Test assumptions have shown that all data has passed the assumption requirements. Based on the results of the partial $t$ test, it shows a hypothesis that the innovation variable is not significant to the development of young entrepreneurs who run culinary businesses in the Binong area of Tangerang. Whereas the risk taking variable has a significant influence on the development of young entrepreneurs who run culinary businesses in the Binong area of Tangerang.
\end{abstract}

Keywords: Innovation, risk taking, entrepreneur,culinary

Abstrak - Penelitian ini dilakukan untuk mengetahui apakah terdapat pengaruh yang signifikan antara variabel inovasi dan pengambilan risiko terhadap perkembangan wirausaha muda yang menjalankan usahanya dalam bidang kuliner wilayah Binong Tangerang. Populasi dari penelitian ini adalah wirausaha muda di bidang kuliner yang berada di wilayah Binong Tangerang. Metode pengambilan sampel dilakukan dengan teknik sampel tak acak bertujuan (Purposive sampling). Metode pengumpulan data dilakukan dengan metode angket / kuesioner dengan memberikan kuesioner kepada 50 responden. Semua teknik analisis data menggunakan program IBM SPSS Statistics 22 . Uji asumsi telah menunjukkan bahwa seluruh data telah lolos dari persyaratan asumsi. Berdasarkan hasil dari uji t parsial menunjukkan sebuah hipotesis bahwa variabel inovasi tidak signifikan terhadap perkembangan wirausaha muda yang menjalankan usaha kuliner di wilayah Binong Tangerang. Sedangkan untuk variabel pengambilan risiko memiliki pengaruh yang signifikan terhadap perkembangan wirausaha muda yang menjalankan usaha kuliner di wilayah Binong Tangerang.

Kata Kunci : Inovasi, pengambilan risiko,wirausaha, kuliner

\subsection{Latar Belakang}

Usaha kecil dan menengah (UKM) saat ini sudah berkembang dari tahun ke tahun sesuai dengan perkembangan zaman baik itu berada di negara berkembang maupun negara maju. Usaha kecil dan menengah (UKM) merupakan salah satu bagian penting dari pekonomian suatu negara ataupun daerah di berbagai negara, termasuk di Indonesia. Usaha kecil dan menengah (UKM) ini juga memiliki peran dalam penyerapan tenaga kerja dan UKM juga sangat produktif dalam menghasilkan tenaga kerja baru dan juga dapat menambah jumlah unit usaha baru yang mendukung pendapatan rumah tangga dari UKM tersebut. Usaha kecil dan menengah (UKM) tersebut memiliki fleksibilitas usaha yang bagus jika dibandingkan dengan usaha yang berkapasitas besar. Jika kita membandingkan UKM di Indonesia pada zaman dahulu dengan zaman sekarang, UKM zaman dahulu belum mendapat perhatian secara penuh dari pemerintah. Sedangkan zaman sekarang, pemerintah sedang menggalakkan program-program untuk peningkatan usaha kecil dan menengah yang ada di Indonesia serta memberikan perhatian yang khusus kepada UKM-UKM tersebut. Peran UKM itu sendiri juga tidak lepas dari para entrepreneur baik itu yang sudah memasuki usia tua maupun yang masih muda, baik yang baru berdiri maupun yang sedang mengembangkan UKM yang sedang dijalaninya. Hanya saja, para entrepreneur yang menjalani UKM di Indonesia ini jumlahnya masih sangat sedikit jika dibandingkan dengan negara lain. Jika melihat data dari yang diberikan oleh Wayan Dipta, Deputi Produksi dan Pemasaran, Kementerian Koperasi dan UKM I Wayan Dipta yang juga Chairman ICSB (International Council for Small Business) Indonesia, per Agustus 2016, menurutnya jika dibandingkan dengan negara lain di ASEAN, rasio entrepreneur di Indonesia per Agustus 2016 sekitar 1,67\%. Angka ini masih tertinggal dengan Singapura yang telah lebih dari $7 \%$, Malaysia lebih dari 5\% dan Thailand sekitar 
4\%. Artinya, dari total penduduk Indonesia yang mencapai 250 juta jiwa, hanya $1,67 \%$ saja yang berwirausaha. Dan bukti lain bahwa jumlah entrepreneur di Indonesia masih kalah jika dibandingkan dengan negara lain adalah dengan data yang dikeluarkan oleh Bank Mandiri per Agustus 2016 bahwa potensi lahirnya entrepreneur di Indonesia hanya sekitar $1.65 \%$ jika dibandingkan dengan negara lain yang sudah lebih maju seperti Singapura dan Malaysia yang memiliki potensi lebih besar dengan jumlah sekitar $7 \%$ dan untuk Malaysia sekitar 5\%. Thailand sekitar 4\%. Artinya, dari total penduduk Indonesia yang mencapai 250 juta jiwa, hanya 1,67\% saja yang berwirausaha. Dan bukti lain bahwa jumlah entrepreneur di Indonesia masih kalah jika dibandingkan dengan negara lain adalah dengan data yang dikeluarkan oleh Bank Mandiri per Agustus 2016 bahwa potensi lahirnya entrepreneur di Indonesia hanya sekitar $1.65 \%$ jika dibandingkan dengan negara lain yang sudah lebih maju seperti Singapura dan Malaysia yang memiliki potensi lebih besar dengan jumlah sekitar $7 \%$ dan untuk Malaysia sekitar 5\%. Hal tersebut bisa dilihat pada gambar 1.1 di bawah ini.

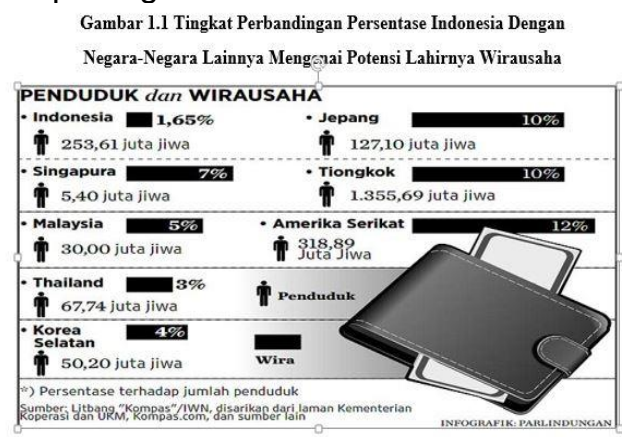

Wirausaha adalah merupakan suatu proses dimana seseorang ataupun suatu kelompok individu menggunakan upaya yang terorganisir \& sarana untuk mencari sebuah peluang dan menciptakan suatu nilai yang tumbuh dengan memenuhi kebutuhan dan keinginan melalui sebuah inovasi \& keunikan, tidak mempedulikan apapun sumber daya yang digunakan pada saat ini (Robbin \& Coulter, 2010) Dasar fundamental dari proses kewirausahaan sering dijumpai pada pola kesuksesan ventura. Selain variasi bisnis, wirausahawan, faktor geografi, dan teknologi, faktor pendukung utama juga mendominasi proses kewirausahaan yang dinamis. (Timmons, 2008) Sehubungan dengan itu, Timmons mengemukakan lima faktor pendorong proses kewirausahaan sebagai berikut :

1. Digerakkan oleh semangat meraih peluang bisnis.
2. Digerakkan oleh wirausahawan terkemuka dan tim kewirausahaannya.

3. Hemat dan kreatif dalam menggunakan sumber daya.

4. Sadar akan perlunya kesesuaian dan keseimbangan.

5. Terintegrasi dan holistik.

Kelima hal di atas merupakan komponen proses kewirausahaan terkontrol yang dapat diukur, dipengaruhi dan diubah. Pendiri dan invenstor memfokuskan diri pada faktor ini saat melakukan proses analisis risiko dan menentukan upaya perubahan untuk meningkatkan peluang sukses ventura. Banyak faktor-faktor yang menentukan bagaimana wirausaha muda mengembangkan UKM mereka (Usaha Kecil Dan Menengah) yang berada di wilayah Binong Tangerang. Salah satu faktor yang paling mendekati hal tersebut adalah inovasi dan pengambilan risiko. Inovasi adalah suatu gagasan baru yang diterapkan untuk memprakarsai atau memperbaiki suatu produk atau proses dan jasa (Robbins, 2012). Jadi, ketika seorang wirausaha muda ingin mengembangkan usaha kecil dan menengah yang sedang mereka jalani, mereka harus memiliki inovasi yang dapat digunakan untuk menciptakan sumber daya produksi yang baru maupun dalam bentuk pengelolahan sumber daya yang ada dengan peningkatan nilai potensi untuk menciptakan sesuatu yang belum ada di usaha kecil dan menengah lainnya. Manajemen risiko adalah suatu bidang ilmu yang membahas tentang bagaimana suatu organisasi menerapkan ukuran dalam memetakan berbagai permasalahan yang ada dengan menempatkan berbagai pendekatan manajemen secara komprehensif dan sistematis. Jadi, pengambilan risiko-dalam ruang lingkup kewirausahaan dapat diartikan sebagai tindakan pengambilan keputusan yang didasarkan pada baik buruk akibat yang mungkin saja dapat ditimbulkan di masa yang akan datang demi memajukan suatu usaha. Dan ketika seorang wirausaha, terutama wirausaha yang masih sangat muda dalam menjalankan usaha mereka, seorang wirausaha pasti mengetahui bahwa ada risiko yang harus dihadapi atau ditanggung oleh wirausaha dalam menjalani usaha kecil dan menengah baik risiko itu ringan maupun berat sekalipun, baik itu menguntungkan maupun merugikan. Jadi, sebagai wirausaha muda, mereka harus memiliki strategi yang tepat untuk mengantisipasi kemungkinan terjadinya risiko yang mungkin ditanggung oleh wirausaha muda. Jadi, kesimpulannya adalah sebagai seorang wirausaha muda dalam menjalankan usaha kecil dan menengah, 
wirasusaha muda harus mengembangkan inovasi dalam menjalankan suatu usaha kecil dan menengah yang sedang dijalankan. Tetapi, mereka juga harus mengetahui apakah risiko yang mungkin dihadapi oleh seorang wirausaha muda. Fokus pada penelitian ini adalah dengan mengacu pada wirausaha muda dalam menjalankan UKM (Usaha Kecil Dan Menengah) mereka dalam bidang kuliner yang berada di wilayah Binong Tangerang . Berdasarkan latar belakang tersebut, penulis merasa tertarik untuk meneliti dan menganalisis "Pengaruh Inovasi Dan Pengambilan Risiko Terhadap Perkembangan Wirausaha Muda Dalam Bidang Kuliner Di Wilayah Binong Tangerang. Tujuan dari penelitian yang dilakukan oleh penulis adalah:

a. Untuk menganalisis pengaruh inovasi terhadap perkembangan wirausaha muda wilayah Binong Tangerang

b. Untuk menganalisis pengaruh pengambilan risiko terhadap perkembangan wirausaha muda di wilayah Binong Tangerang

c. Untuk menganalisis pengaruh inovasi dan pengambilan risiko terhadap perkembangan wirausaha muda di wilayah Binong Tangerang

\subsection{Tinjauan Pustaka} pengorganisasian, pengarahan, dan pengendalian terhadap penggunaan sumber daya untuk mencapai tujuan. Berdasarkan pengertian di atas, dapat dikatakan bahwa ada hubungan antara variabel-variabel independen seperti inovasi dan pengambilan risiko terhadap teori manajemen seperti yang dijelaskan oleh Schermerhorn di atas, terutama dalam kaitannya dalam bidang kewirausahaan. Schermerhorn (2012). Perkembangan usaha kecil menengah adalah kemampuan seorang pengusaha kecil untuk mensosialisasikan dirinya kepada kebutuhan pangsa pasar sehingga ada perbaikan taraf hidup pada diri seorang pengusaha (Purwanti 2012 ,hal.21). Ketika mereka terlibat dalam suatu bisnis, mereka telah memperhitungkan dengan pemikiran yang matang. Mereka selalu menghindari untuk mengambil risiko yang tidak perlu. Dan itu menunjukkan bahwa variabel pengambilan risiko mempunyai pengaruh terhadap perkembangan wirausaha muda yang menjalankan UKM nya dalam bidang kuliner di wilayah Binong Tangerang. Dari semua teori di atas, Ada manfaat dari beberapa kaitan antara variabel independen (Inovasi dan pengambilan risiko) terhadap variabel dependen (Perkembangan wirausaha di wilayah Binong Tangerang) terutama bagi bidang ilmu, khususnya bagi para mahasiswa/i yang mengambil jurusan manajemen perhotelan. Menurut Reader's Digest Indonesia (2012), mengutip dari tulisan Yoris Sebastian dari majalah Femina, ada beberapa manfaat inovasi yang dibutuhkan oleh seorang wirausaha dalam menjalankan dan mengembangkan suatu bisnis atau usahanya itu sendiri. Yang pertama adalah inovasi dibutuhkan agar bisnis kita selalu relevan bagi konsumen, yang kedua adalah untuk mengganti suatu produk yang masa hidupnya sangat pendek, dan yang terakhir adalah untuk memberikan keuntungan yang lebih besar bagi bisnis yang kita sedang jalani.

Berdasarkan penjelasan di atas, dapat dibuktikan bahwa manfaat dari inovasi dan pengambilan risiko bagi bidang kewirausahaan memiliki pengaruh yang signifikan apabila dikaitkan dengan teori manajemen seperti yang dijelaskan oleh Schermerhorn di atas. Menurut Hisrich dan Kearney (2013), Inovasi adalah proses yang dimulai dengan sebuah ide; berlangsung dengan berkembangnya penemuan; dan hasil di dalam pengembangan atau peningkatan produk, jasa, proses, atau kemajuan teknologi adalah sebagai bagian dari inovasi organisasi.

Menurut Undang-Undang Republik Indonesia Nomor 18 Tahun 2002 inovasi adalah kegiatan penelitian, pengembangan, dan/atau perekayasaan yang bertujuan mengembangkan penerapan praktis nilai dan konteks ilmu pengetahuan yang baru, atau cara baru untuk menerapkan ilmu pengetahuan dan teknologi yang telah ada ke dalam produk atau proses produksi.

Menurut Ancok (2012) berpendapat bahwa inovasi adalah pengenalan dan penerapan dengan sengaja gagasan, proses, produk, dan prosedur yang baru pada unit yang menerapkannya,yang dirancang untuk memberikan keuntungan bagi individu, kelompok, organisasi dan masyarakat luas.

Menurut Kasali, dkk. (2010) mendefinisikan risiko sebagai adanya konsekuensi, sebagai dampak adanya ketidakpastian, yang memunculkan dampak yang merugikan pelaku usaha. Sebaliknya, konsekuensi yang memunculkan dampak yang menguntungkan tidak dianggap sebagai risiko. Konsekuensi positif ini dianggap sebagai keuntungan yang diharapkan. Toleransi terhadap risiko, merupakan seberapa besar kemampuan dan kreativitas seseorang dalam mengantisipasi besar kecilnya suatu risiko yang diambil untuk mendapatkan penghasilan yang diharapkan (Pratiwi, 2013). 
Menurut Tama (2010) berpendapat bahwa semakin besar seseorang pada kemampuan diri sendiri, semakin besar pula keyakinanya terhadap kesanggupan mendapatkan hasil dari keputusanya dan semakin besar keyakinanya untuk mencoba apa yang dilihat dari orang lain yang mungkin juga menghadapi sebuah risiko.

Menurut Kasali, dkk. (2010) mendefinisikan perkembangan wirausaha adalah seorang yang "moving forward", maju terus ke depan. Usahanya tumbuh dari waktu ke waktu, dari satu kedai menjadi lima, sepuluh, seratus, lalu seribu. Dari warung kecil menjadi usaha besar. Dari lima karyawan menjadi puluhan, ratusan, atau mungkin saja ribuan karyawan. Tak peduli apakah dia seniman, wartawan, pekerja sosial, atau industriawan. Siapa saja yang melakukannya, dia bisa disenut entrepreneur asalkan bertumpu pada fondasi petumbuhan.

Hasil penelitian ini juga didukung oleh teori yang dikemukakan oleh Hadiyati (2010) yang berpendapat bahwa kewirausahaan (entrepreneur) cenderung berorentasi pada inovasi (innovation) yang didasarkan pada ide baru dan keadaan pasar yang tidak berorentasi pada konsumen, atau yang dikendalikan oleh perkiraan keinginan dan kebutuhan pasar. Wirausahawan (entrepreneur) menargetkan pasarnya melalui seleksi dengan pendekatan dari bawah ke atas (bottom-up) dan rekomendasi dari konsumen dan pengaruh kelompok lainnya dari atas ke bawah (top-down) yang menargetkan dan memposisikan prosesnya.

Oktarilis (2012) menyatakan bahwa dalam pengambilan keputusan pelaku bisnis atau seorang entrepreneur sebaiknya mempertimbangkan tingkat toleransi akan adanya risiko. Seorang entrepreneur dapat dikatakan risk averse (menghindari risiko) dimana mereka hanya mau mengambil peluang tanpa risiko, dan seorang entrepreneur dikatakan risk lover (menyukai risiko) dimana mereka mengambil peluang dengan tingkat risiko yang tinggi. Keinginian seorang entrepreneur untuk terus berjuang mencari peluang sampai memperoleh hasil didorong oleh keberanian orang tersebut untuk menghadapi risiko dan didukung oleh komitmen yang kuat. Oktarilis (2012) menyatakan bahwa kemauan dan kemampuan untuk mengambil risiko merupakan salah satu nilai utama dalam berwirausaha

\subsubsection{Penelitian Yang Relevan}

Penelitian lain yang relevan dengan penelitian ini adalah penelitian yang dilakukan oleh Hatta (2014) yang berjudul "Analisis Pengaruh Inovasi, Pengambilan Resiko,
Otonomi, Dan Reaksi Proaktif Terhadap Kapabilitas Pemasaran UKM Kuliner Daerah Di JABODETABEK". Hasil penelitian yang didapat membuktikan terdapat hubungan yang positif antara variabel independen, yaitu inovasi dan pengambilan resiko terhadap variabel dependen yaitu kapabilitas pemasaran UKM Kuliner Daerah di JABODETABEK.

Penelitian lain yang relevan dengan penelitian ini adalah penelitian yang dilakukan oleh Behroozi (2012) yang berjudul "Survey On University Role In Preparation Graduated Students In To Entrepreneurs universities Towards A Conceptual Framework: Iran's Perspective". Hasil yang didapat membuktikan terdapat hubungan yang positif antara variabel independen, yaitu inovasi dan pengambilan risiko terhadap variabel dependen yaitu mempersiapkan mahasiswa yang baru lulus untuk menjadi seorang entrepreneur dalam mengembangkan usaha.

\subsubsection{Rerangka Pemikiran}

Dari beberapa penelitian yang telah dilakukan sebelumnya yang membahas tentang perkembangan wirausaha, penulis tertarik untuk melakukan penelitian kembali untuk mengetahui pengaruh dari inovasi dan pengambilan resiko terhadap perkembangan wirausaha muda dalam bidang kuliner di wilayah Binong Tangeramg.

Berdasarkan definisi, variabel, kerangka teori dan penelitian relevan diatas, didapat perkembangan wirausaha muda sebagai variabel $Y$ dan dipengaruhi oleh inovasi dan pengambilan resiko sebagai variabel $X$. Maka dikemukakan rerangka pemikiran sebagai berikut:

\begin{tabular}{|c|}
\hline Inovasi $(\mathrm{X} 1)$ \\
\hline $\begin{array}{c}\text { Pengambilan } \\
\text { Risiko }(\mathrm{X} 2)\end{array}$
\end{tabular} \begin{tabular}{c}
$\begin{array}{c}\text { Perkembangan } \\
\text { wirausaha muda } \\
\text { dalam bidang } \\
\text { kuliner di wilayah } \\
\text { Binong } \\
\text { Tangerang }\end{array}$ \\
\hline
\end{tabular}

\section{Sumber : Hasil Analisis}

\section{Gambar 2.1. Rerangka Pemikiran}

Berdasarkan rerangka pemikiran di atas maka dapat dirumuskan hipotesis sebagai berikut :

$\mathrm{H} 1$ : Terdapat pengaruh antara inovasi terhadap perkembangan wirausaha muda dalam bidang kuliner di wilayah Binong Tangerang.

H2 : Terdapat pengaruh antara pengambilan risiko terhadap perkembangan wirausaha muda dalam bidang kuliner di wilayah Binong Tangerang.

\subsection{Metode Penelitian}

Desain penelitian ini adalah penelitian bersifat kuantitatif dengan pengujian hipotesis 
yang memberikan gambaran terhadap suatu variabel-variabel tertentu, desain penelitian ini juga menerangkan hubungan antar variabel independen terhadap variabel dependen, menguji hipotesis-hipotesis dari masingmasing hubungan antar variabel, membuat prediksi serta mendapatkan makna dan implikasi dari suatu masalah masing-masing variabel tertentu yang ingin dipecahkan. Dalam penelitian ini, yang menjadi variabel dependen adalah pengembangan wirausaha muda dalam menjalankan usahanya di bidang kuliner, sedangkan variabel independennya adalah inovasi dan pengambilan risiko. Populasi yang akan diteliti untuk penelitian ini adalah para pemilik UKM yang menjalankan usahanya di bidang kuliner yang berada di wilayah binong Tangerang. Dalam penelitian ini, peneliti menggunakan teknik pemilihan sampel tak acak bertujuan (Purposive sampling). Teknik ini disebut juga sebagai teknik judgmental (Penilaian). Peneliti mengambil sampel sebanyak 50 responden, di mana responden tersebut terdiri dari para pemilik UKM dalam bidang kuliner yang berada di wilayah Binong Tangerang Menurut Sekaran dan Bougie (2016) dalam menentukan ukuran sampel peneliti dapat menggunakan analisis multivariate atau analisis regresi ganda. Dimana ukuran sampel haruslah beberapa kali (10 kali atau lebih) dari jumlah variabel dalam penelitian. Berdasarkan teori ini, peneliti menentukan 30 sampel dengan perhitungan $10 \times 3$ (2 variabel independen +1 variabel dependen), maka jumlah sampel sebanyak 30 (Riadi, 2014). Hipotesis yang diajukan dalam penelitian ini, variabel independen (variabel bebas) dalam penelitian ini adalah inovasi (X1), pengambilan risiko (X2), dan variabel dependen (Variabel terikat) adalah perkembangan wirausaha dalam menjalankan UKM nya dalam bidang kuliner (Y). Dalam penelitian ini alat ukur yang digunakan adalah Skala Likert. Sekaran dan Bougie (2016) menyatakan bahwa pernyataan-pernyataan sikap pada skala Likert terdiri atas pernyataan yang bersifat favorabel (positif) dan tidak favorabel (negatif). Yang menjadi penilaian akan tanggapan responden terhadap angket penelitian ini dapat dibagi menjadi lima kategori, yaitu 'sangat setuju', 'setuju', 'netral', 'tidak setuju', dan 'sangat tidak setuju. Uji reliabilitas tersebut digunakan dengan perhitungan melalui program IBM SPSS Statistics 22. Metode perhitungan reliabilitas dilakukan dengan metode Cronbach's Alpha. Suatu instrumen dinyatakan reliabel bila koefisien reliabilitas minimal 0,6 (Sekaran dan Bougie, 2016). Uji validitas tersebut digunakan dengan perhitungan melalui program IBM
SPSS Statistics 22. Sebuah indikator dinyatakan valid atau tidak dilihat dari cronbach alpha yang terdapat dalam kolom Corrected Item-Total Correlation. valid bila nilai $r$ hitung $>r$ tabel, dan bernilai positif melebihi 0,3 Metode yang digunakan untuk analisis data menggunakan metode regresi berganda. Data yang terkumpul akan diolah dan dianalisis dengan menggunakan program IBM SPSS Statistics 22 secara keseluruhan Analisis regresi linear ganda adalah analisis yang dilakukan untuk mengetahui besarnya pengaruh beberapa variabel independen terhadap variabel dependen dan memprediksi variabel dependen dengan variabel independen.

Persamaan regresi linear berganda adalah sebagai berikut :

$Y^{\prime}=a+b_{1} X_{1}+b_{2} X_{2}+e$ dimana:

$$
\begin{array}{ll}
\mathrm{Y}^{\prime} & =\text { Perkembangan wirausaha } \\
\mathrm{a} & =\text { Konstanta } \\
\mathrm{b}_{1}, \mathrm{~b}_{2} & =\text { Koefisien regresi } \\
\mathrm{X}_{1} & =\text { Inovasi } \\
\mathrm{X}_{2} & =\text { Pengambilan risiko } \\
\mathrm{e} & =\text { Error }
\end{array}
$$

Dengan melihat nilai koefisien regresi pada persamaan di atas, maka dapat diketahui besarnya pengaruh variabel-variabel bebas terhadap variabel terikat. Uji regresi ganda ini dilakukan dengan bantuan program IBM SPSS Statistics 22.

Uji $\mathrm{F}$ atau dikenal juga dengan ANOVA digunakan untuk mengetahui pengaruh variabel independen terhadap variabel dependen dan menguji apakah model yang dibuat signifikan atau tidak signifikan. Apabila nilai sig $<\alpha$, maka hipotesis ditolak, ini berarti paling sedikit terdapat satu variabel independen yang memiliki pengaruh yang signifikan terhadap variabel dependen.Sebaliknya apabila sig $\geq \alpha$, maka hipotesis tidak ditolak, ini berarti tidak terdapat pengaruh yang signifikan dari semua variabel dependen secara bersama-sama terhadap variabel dependen (Sekaran dan Bougie 2016,hal.312)

Uji $t$ digunakan untuk menguji kebenaran hipotesis yang menyatakan dua atau lebih mean dari kelompok. Pengujian dilakukan dengan menggunakan signifikan level 0,05. Penerimaan dan penolakan hipotesis dilakukan dengan kriteria: Jika nilai signifikan > 0,05 maka hipotesis ditolak (koefisien regresi tidak signifikan). Ini berarti secara parsial variabel independen tidak mempunyai pengaruh signifikan terhadap variabel dependen.

Jika nilai signifikan $<0,05$ maka hipotesis diterima (koefisien regresi signifikan). Ini 
berarti secara parsial variabel independen tersebut mempunyai pengaruh yang signifikan terhadap variabel dependen (Sekaran dan Bougie,2016 hal.310).

Pengujian koefisien determinasi $\left(R^{2}\right)$ bertujuan untuk mengetahui kontribusi dari variabelvariabel independen terhadap variabel dependen

\subsection{Hasil dan Pembahasan}

Subyek yang penulis gunakan untuk penelitian ini adalah sebanyak 50 responden, dimana seluruh respondennya merupakan pemilik Usaha Kecil dan Menengah (UKM) yang dijalankan dan dikembangkan oleh wirausaha muda dalam bidang kuliner yang berada di wilayah Binong Tangerang. Dalam deskripsi subyek penelitian ini akan diuraikan berbagai macam karakteristik dari 50 orang responden yang ditinjau dari jenis kelamin, jenis usaha yang saat ini sedang dijalankan, lama usaha berjalan, dan pendapatan per tahunnya.

Tabel 4.1 Hasil Uji Validitas Variabel Inovasi

\begin{tabular}{|c|c|c|}
\hline Pernyataan & Corrected item-otal correlation & Validitas \\
\hline II & 0.742 & Valid \\
\hline D & 0.817 & Valit \\
\hline B & 0.663 & Valid \\
\hline I4 & 0.646 & Valid \\
\hline E & 0.771 & Valid \\
\hline I6 & 0.376 & Valiti \\
\hline $\bar{T}$ & 0.782 & $\begin{array}{lll}\text { Valid } \\
\text { Val }\end{array}$ \\
\hline IS & 0.747 & Valite \\
\hline
\end{tabular}

Dari hasil tabel 4.1 tersebut, dapat dilihat bahwa seluruh pernyataan mengenai variabel inovasi memiliki corrected item-total correlation yang lebih besar dari 0,3 sehingga dapat dikatakan bahwa seluruh butir pernyataanpernyataan mengenai variabel inovasi adalah valid

Tabel 4.2 Hasil Uji Validitas Variabel Pengambilan Risiko

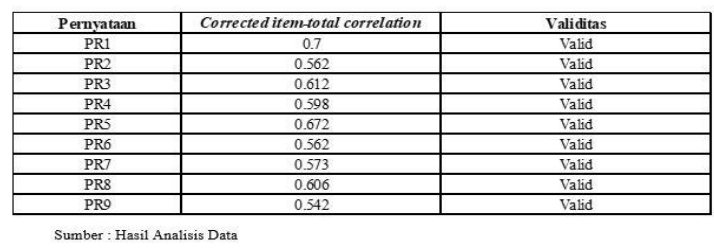

Dari hasil tabel 4.2 tersebut, dapat dilihat bahwa seluruh pernyataan mengenai variabel pengambilan resiko memiliki corrected item-total correlation yang lebih besar dari 0,3 sehingga dapat dikatakan bahwa seluruh butir pernyataan-pernyataan mengenai variabel pengambilan resiko adalah valid.

Tabel 4.3 Hasil Uji Validitas Variabel Perkembangan Wirausaha

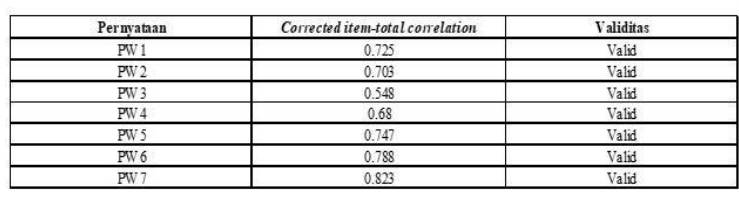

Sumber : Hasil Analisis Data
Dari hasil tabel 4.3 tersebut, dapat dilihat bahwa seluruh pernyataan mengenai variabel perkembangan wirausaha memiliki corrected item-total correlation yang lebih besar dari 0,3 sehingga dapat dikatakan bahwa seluruh butir pernyataan-pernyataan mengenai variabel perkembangan wirausaha adalah valid

Tabel 4.4 Hasil Uji Reliabilitas Variabel Inovasi, Pengambilan Risiko, Dan Perkembangan Wirausaha

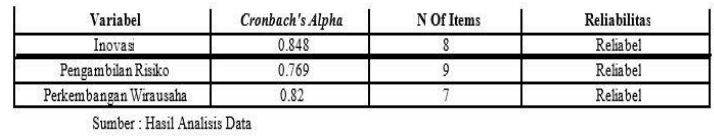

Sumber: Hasil Analisis Data

Dari tabel 4.4 yang merupakan hasil pengujian reliabilitas diketahui bahwa nilai Cronbach Alpha untuk semua variabel di atas lebih besar dari 0,6, sehingga dapat dinyatakan bahwa pengujian semua variabel baik variabel independen maupun dependen di atas adalah reliabel.

Tabel 4.5 Hasil Statistik Deskriptif Karakteristik Responden Berdasarkan jenis Kelamin
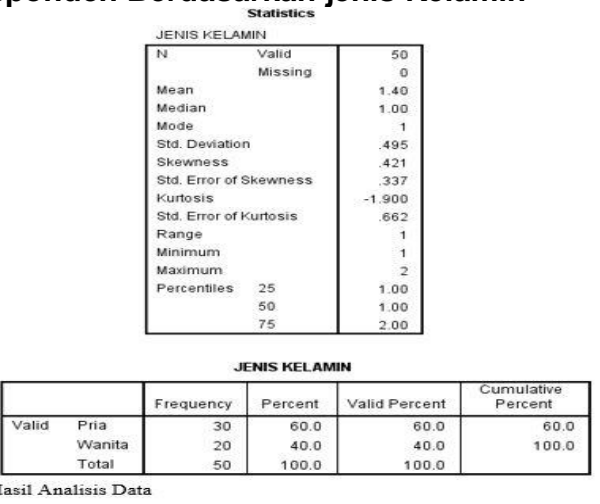

Berdasarkan tabel di atas, dapat dinyatakan bahwa untuk nilai minimum dari deskripsi subyek penelitian berdasarkan jenis kelamin adalah 1, sedangkan untuk nilai maksimum itu sendiri adalah 2 . Untuk nilai tendesi sentral itu sendiri dari penelitian tersebut adalah untuk mean nya memiliki nilai 1.40, sedangkan untuk median itu sendiri memiliki nilai 1.00 , dan untuk mode itu sendiri memiliki nilai 1. Dan untuk ukuran variabilitas mengenai penelitian ini dia memiliki rentang dengan nilai 1 dan deviasi standar dengan nilai 0.495 . Berikut adalah gambar dari deskripsi subyek penelitian berdasarkan jenis kelamin

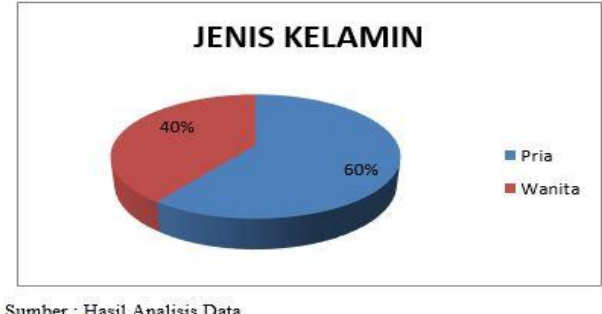

Gambar 4.1 Karakteristik Responden Berdasarkan Jenis Kelamin 
Berdasarkan gambar 4.1 di atas, dapat diketahui bahwa dari 50 responden yang berdasarkan jenis kelamin, responden yang berjenis kelamin pria berjumlah sebanyak 30 orang $(60 \%)$ dan responden yang berjenis kelamin wanita berjumlah sebanyak 20 orang (40\%). Dengan ini dapat disimpulkan bahwa mayoritas responden dalam penelitian ini berjenis kelamin pria.

Tabel 4.6 Hasil Statistik Deskriptif Karakteristik Responden Berdasarkan Jenis Usaha

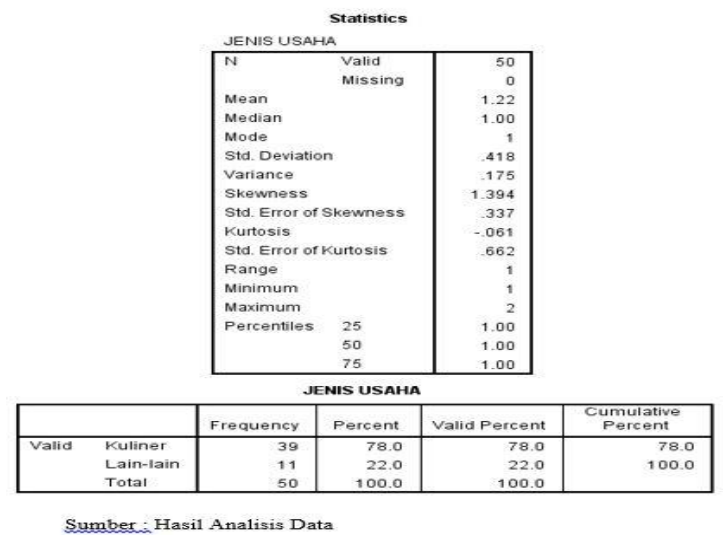

Berdasarkan tabel di atas, dapat dinyatakan bahwa untuk nilai minimum dari deskripsi subyek penelitian berdasarkan jenis usaha adalah 1, sedangkan untuk nilai maksimum itu sendiri adalah 2. Untuk nilai tendesi sentral itu sendiri dari penelitian tersebut adalah untuk mean nya memiliki nilai 1.22, sedangkan untuk median itu sendiri memiliki nilai 1.00 , dan untuk mode itu sendiri memiliki nilai 1. Dan untuk ukuran variabilitas mengenai penelitian ini dia memiliki rentang dengan nilai 1 dan deviasi standar dengan nilai 0.418. Berikut adalah gambar dari deskripsi subyek penelitian berdasarkan jenis usaha.

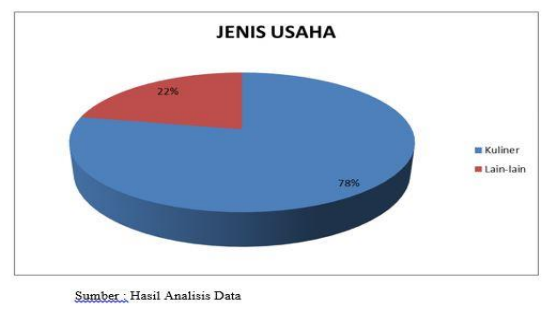

Gambar 4.2 Karakteristik Responden Berdasarkan Jenis Usaha

Berdasarkan gambar 4.2 di atas, dapat diketahui bahwa dari 50 responden yang berdasarkan jenis usaha, responden yang memiliki jenis usaha di bidang kuliner berjumlah sebanyak 39 orang $(78 \%)$ dan responden yang memiliki jenis usaha di bidang usaha lain-lain berjumlah sebanyak 11 orang (22\%). Dengan ini dapat disimpulkan bahwa mayoritas responden dalam penelitian ini memiliki jenis usaha di bidang kuliner.

Tabel 4.7 Hasil Statistik Deskriptif Karakteristik Responden Berdasarkan Lama Usaha

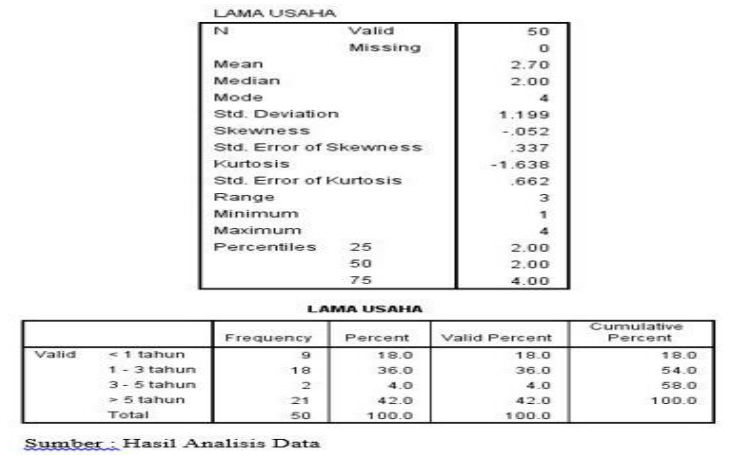

Berdasarkan tabel di atas, dapat dinyatakan bahwa untuk nilai minimum dari deskripsi subyek penelitian berdasarkan lama usaha adalah 1, sedangkan untuk nilai maksimum itu sendiri adalah 4 . Untuk nilai tendesi sentral itu sendiri dari penelitian tersebut adalah untuk mean nya memiliki nilai 2.70, sedangkan untuk median itu sendiri memiliki nilai 2.00, dan untuk mode itu sendiri memiliki nilai 4. Dan untuk ukuran variabilitas mengenai penelitian ini dan memiiliki rentang dengan nilai 3 dan deviasi standar dengan nilai 1.199. Berikut adalah gambar dari deskripsi subyek penelitian berdasarkan lama usaha

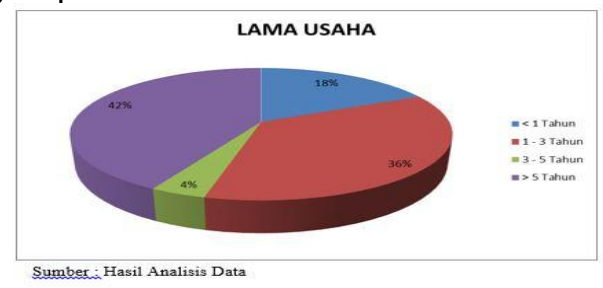

Gambar 4.3 Karakteristik Responden Berdasarkan Lama Usaha

Berdasarkan gambar 4.3 di atas, dapat diketahui bahwa dari 50 responden yang berdasarkan lama usaha, responden yang memiliki lama usaha $<1$ tahun berjumlah sebanyak 9 orang (18\%), responden yang memiliki lama usaha di antara 1 - 3 tahun berjumlah sebanyak 18 orang (36\%), responden yang memiliki lama usaha di antara 3 - 5 tahun berjumlah sebanyak 2 orang (4\%), dan responden yang memiliki lama usaha $>5$ tahun berjumlah sebanyak 21 orang (42\%). Dengan ini dapat disimpulkan bahwa mayoritas responden dalam penelitian ini memiliki lama usaha $>5$ tahun

Tabel 4.8 Hasil Statistik Deskriptif Karakteristik

Responden Berdasarkan Pendapatan Usaha

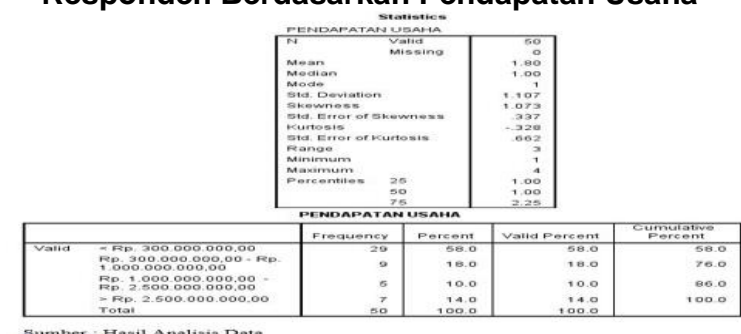

Berdasarkan tabel di atas, dapat dinyatakan bahwa untuk nilai minimum dari 
deskripsi subyek penelitian berdasarkan pendapatan usaha adalah 1 , sedangkan untuk nilai maksimum itu sendiri adalah 4 . Untuk nilai tendesi sentral itu sendiri dari penelitian tersebut adalah untuk mean nya memiliki nilai 1.80 , sedangkan untuk median itu sendiri memiliki nilai 1.00 , dan untuk mode itu sendiri memiliki nilai 1. Dan untuk ukuran variabilitas mengenai penelitian ini dia memiiliki rentang dengan nilai 3 dan deviasi standar dengan nilai 1.107. Berikut adalah gambar dari deskripsi subyek penelitian berdasarkan pendapatan usaha.

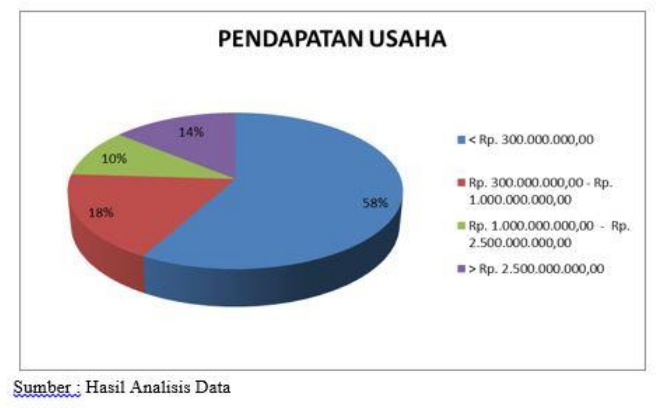

Gambar 4.4 Karakteristik Responden Berdasarkan Pendapatan Usaha

Berdasarkan gambar 4.4 di atas, dapat diketahui bahwa dari 50 responden yang berdasarkan pendapatan usaha, responden yang memiliki pendapatan usaha < Rp. $300.000 .000,00$ berjumlah sebanyak 29 orang (58\%), responden yang memiliki pendapatan usaha di antara Rp. 300.000.000,00 - Rp. $1.000 .000 .000,00$ berjumlah sebanyak 9 orang $(18 \%)$, responden yang memiliki pendapatan usaha di antara Rp. 1.000.000.000,00 - Rp. $2.500 .000 .000,00$ berjumlah sebanyak 5 orang $(10 \%)$, dan responden yang memiliki pendapatan usaha > Rp. 2.500.000.000,00 berjumlah sebanyak 7 orang (14\%). Dengan ini dapat disimpulkan bahwa mayoritas responden dalam penelitian ini memiliki pendapatan usaha < Rp. 300.000.000,00.

Tabel 4.9 Statistik Deskriptif Variabel Inovasi

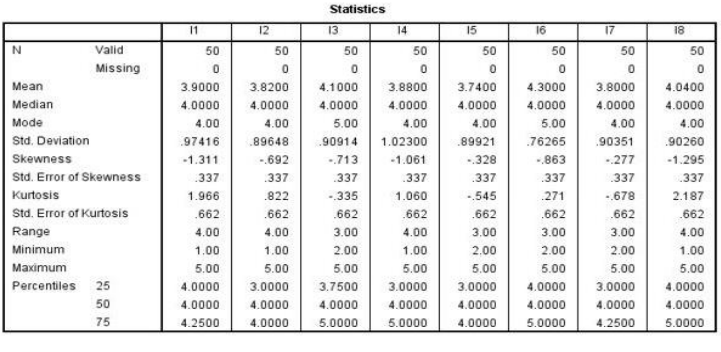

Sumber: Hasil Analisis Data

Berdasarkan tabel di atas, dapat dinyatakan bahwa untuk nilai minimum dari deskripsi obyek penelitian berdasarkan variabel inovasi dari indikator variabel inovasi dengan kode 11, 12, 14, dan 18 adalah 1.00, sedangkan untuk indikator variabel inovasi dengan kode 13, 15, 16, dan 17 adalah 2.00.
Dan untuk nilai maksimum dari variabel inovasi dengan kode 11 sampai 18 adalah 5.00. Meannya untuk masing-masing indikator dari variabel tersebut adalah 11 nilainya adalah 3.900 , 12 nilainya adalah 3.820 , I3 nilainya adalah 4.100, 14 nilainya adalah $3.880,15$ nilainya adalah 3.740 , 16 nilainya adalah 4.300 , 17 nilainya adalah 3.800 , dan 18 nilainya adalah 4.040. Median untuk semua indikator dari variabel tersebut adalah 4.000. Mode dari indikator variabel tersebut adalah $11,12,14,15$, 17, dan 18 adalah 4.00. Dan mode untuk indikator variabel inovasi dengan kode 13 dan 16 adalah 5.00. Range dari indikator variabel inovasi dengan kode $11,12,14$, dan 18 adalah 4.00. Dan untuk kode 13, 15, 16, dan 17 adalah 3.00. Dan standar deviasi untuk masingmasing kode tersebut adalah 11 nilainya 0.9742 , 12 nilainya 0.8965 , I3 nilainya adalah $0.9091,14$ nilainya $1.0230,15$ nilainya adalah $0.8992,16$ nilainya adalah $0.7627,17$ nilainya adalah 0.9035 , 18 nilainya adalah 0.9026

Tabel 4.10 Statistik Deskriptif Variabel Pengambilan Risiko

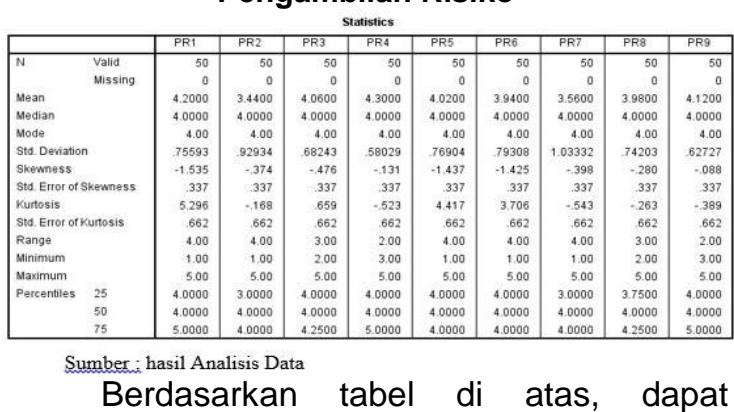
dinyatakan bahwa untuk nilai minimum dari deskripsi obyek penelitian berdasarkan variabel pengambilan resiko dari indikator variabel pengambilan resiko dengan kode PR1, PR2, PR5, PR6, dan PR7 nilainya adalah 1.00. Untuk kode PR3 dan PR8 nilainya adalah 2.00. Dan untuk kode PR4 dan PR9 nilainya adalah 3.00. Untuk maksimum dari seluruh kode masing-masing indikator tersebut adalah 5.00. Mean dari masing-masing indikator tersebut adalah PR1 nilainya 4.20, PR2 nilainya 3.44 , PR3 nilainya 4.06 , PR4 nilainya 4.30, PR5 nilainya 4.02 , PR6 nilainya 3.94 , PR7 nilainya 3.56 , PR8 nilainya 3.98 , dan PR9 nilainya 4.12. Median dari semua indikator dari variabel tersebut adalah 4.00. Mode dari seluruh indikator dari variabel tersebut adalah 4.00. Range dari masing-masing kode dari indikator variabel tersebut adalah untuk PR1, PR2, PR5, PR6, dan PR7 nilainya adalah 4.00, untuk PR3 dan PR8 nilainya adalah 3.00, dan untuk PR4 dan PR9 nilainya adalah 2.00. Dan untuk standar deviasi untuk masing-masing indikator tersebut adalah PR1 nilainya 0.756 , PR2 nilainya 0.93 , PR3 nilainya 0.68 , PR4 nilainya 0.58 , PR5 nilainya 0.77 , PR6 nilainya 
0.79 , PR7 nilainya 1.03 , PR8 nilainya 0.74 , dan PR9 nilainya 0.63

Tabel 4.11 Statistik Deskriptif Variabel Perkembangan Wirausaha

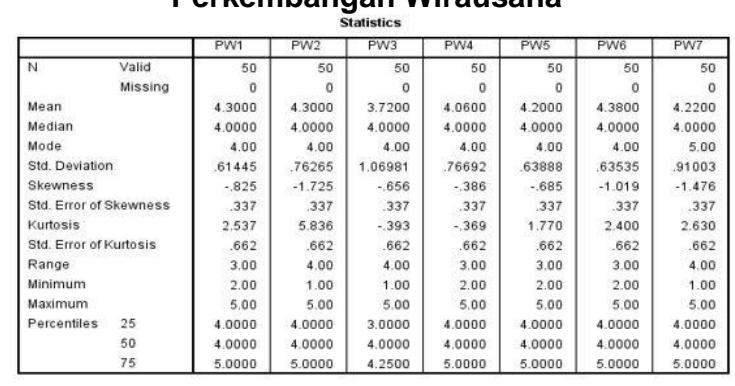

Sumber : Hasil Analisis Data

Berdasarkan tabel di atas, dapat dinyatakan bahwa untuk nilai minimum dari deskripsi obyek penelitian berdasarkan variabel perkembangan wirausaha dari indikator variabel perkembangan wirausaha dengan kode PW1, PW4, PW5, dan PW6 nilainya adalah 2.00. Untuk kode PW2, PW3, dan PW7 nilainya adalah 1.00. Untuk maksimum dari seluruh kode masing-masing indikator tersebut adalah 5.00. Mean dari masing-masing indikator tersebut adalah PW1 nilainya 4.30, PW2 nilainya 4.30, PW3 nilainya 3.72, PW4 nilainya 4.06 , PW5 nilainya 4.20 , PW6 nilainya 4.38, dan PW7 nilainya 4.22. Median dari semua indikator dari variabel tersebut adalah 4.00. Mode dari seluruh indikator dari variabel tersebut adalah 4.00 dan khusus untuk indikator variabel perkembangan wirausaha dengan kode PW7 nilainya 5.00. Range dari masing-masing kode dari indikator variabel tersebut adalah untuk PW1, PW4, PW5, dan PW6 adalah 3.00. Dan range untuk indikator variabel perkembangan wirausaha dengan kode PW2, PW3, dan PW7 adalah 4.00. Untuk standar deviasi untuk masingmasing indikator tersebut adalah PW1 nilainya 0.61 , PW2 nilainya 0.76 , PW3 nilainya 1.07 , PW4 nilainya 0.77 , PW5 nilainya 0.64 , PW6 nilainya 0.64 , PW7 nilainya 0.91 .

Tabel 4.12 Hasil Analisis Regresi Berganda

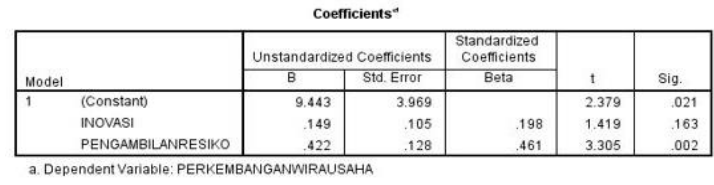

Sumber: Hasil Analisis Data

Dari tabel 4.12 di atas, dapat dirumuskan persamaan regresinya adalah yaitu dari tabel coefficients diketahui nilai intersep sebesar 9.443 dan koefisien regresi untuk inovasi (I) sebesar 0.149 dengan tingkat signifikansi 0.163 sedangkan nilai koefisien regresi untuk pengambilan resiko (PR) sebesar 0.422 dengan tingkat signifikansi 0.002 .
Dengan demikian persamaan regresi adalah $\mathrm{Y}=\mathrm{a}+\mathrm{b} 1 \mathrm{I}+\mathrm{b} 2 \mathrm{PR}$, dimana $\mathrm{Y}^{\prime}=9.443+$ $0.149 I+0.422 P R$

\begin{tabular}{|c|c|c|c|c|c|c|}
\hline \multicolumn{2}{|c|}{ Model } & $\begin{array}{l}\text { Sum of } \\
\text { Squares }\end{array}$ & df & Mean Square & $\mathrm{F}$ & Sig. \\
\hline \multirow[t]{3}{*}{1} & Regression & 248.692 & 2 & 124.346 & 12.577 & $.000^{6}$ \\
\hline & Residual & 464.688 & 47 & 9.887 & & \\
\hline & Total & 713.380 & 49 & & & \\
\hline \multicolumn{7}{|c|}{ a. Dependent Variable: PERKEMBANGANWIRAUSAHA } \\
\hline \multicolumn{7}{|c|}{ b. Predictors: (Constant), PENGAMBILANRESIKO, INOVASI } \\
\hline \multicolumn{7}{|c|}{ Sumber: Hasil Analisis Data } \\
\hline
\end{tabular}

Dari tabel anova diketahui bahwa signifikansi $0,000(0,000<0,05)$ yang berarti persamaan regresi dapat digunakan untuk memprediksi performa atau paling sedikit ada satu variabel bebas (Inovasi atau pengambilan risiko) yang mempengaruhi variabel $Y$ (Perkembangan Wirausaha).

Tabel 4.14 Uji t

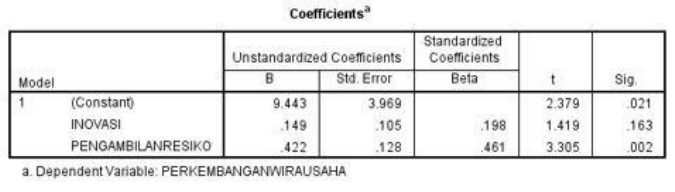

Sumber : Hasil Analisis Data

Berdasarkan hasil analisis data pada bagian hasil uji $\mathrm{t}$ (Uji parsial) pada tabel 4.14 menunjukkan bahwa nilai signifikansi untuk variabel inovasi sebesar 0.163 yaitu lebih besar dari $\alpha=0.05$. Sedangkan kriteria untuk melihat apakah suatu hipotesis dari suatu variabel itu diterima atau ditolak adalah jika nilai signifikansinya $<0.05$ dinyatakan bahwa hipotesis tersebut diterima yang berarti bahwa variabel independen tersebut mempunyai pengaruh yang signifikan terhadap variabel dependen tersebut. Berdasarkan hasil analisis data beserta dengan pernyataan di atas, dapat disimpulkan bahwa tidak terdapat pengaruh yang signifikan antara variabel inovasi dengan variabel perkembangan wirausaha.. berdasarkan hasil analisis data pada bagian hasil uji $\mathrm{t}$ (Uji parsial) pada tabel 4.14 menunjukan bahwa nilai signifikansi untuk variabel pengambilan risiko sebesar 0.002 yaitu lebih kecil dari $\alpha=0.05$. Sedangkan kriteria untuk melihat apakah suatu hipotesis dari suatu variabel itu diterima atau ditolak adalah jika nilai signifikansinya $<0.05$ dinyatakan bahwa hipotesis tersebut diterima yang berarti bahwa variabel independen tersebut mempunyai pengaruh yang signifikan terhadap variabel dependen tersebut.

Tabel 4.15 Uji Koefisien Determinasi

\begin{tabular}{|l|l|l|c|c|}
\hline Model & R & R Square & $\begin{array}{c}\text { Adjusted R } \\
\text { Square }\end{array}$ & $\begin{array}{c}\text { Std. Error of } \\
\text { the Estimate }\end{array}$ \\
\hline 1 & $.590^{\mathrm{a}}$ & .349 & .321 & 3.14436 \\
\hline
\end{tabular}
a. Predictors: (Constant), PENGAMBILANRESIKO, INOVASI
Sumber : Hasil Analisis Data

Dari hasil perhitungan SPSS, dapat dilihat pada tabel Model Summary (tabel 4.15) diperoleh bahwa nilai $R$ Square adalah 0,349 
atau $34.9 \%$. Artinya besarnya variabel perkembangan wirausaha dapat dijelaskan oleh variabel independen, yaitu inovasi dan pengambilan risiko sebesar $34.9 \%$ sedangkan sisanya sebesar $65.1 \%$ dijelaskan oleh faktor lain di luar variabel-variabel independen tersebut.

Dapat disimpulkan bahwa diperoleh hipotesis sementara mengenai adanya pengaruh yang signifikan antara variabel inovasi terhadap variabel perkembangan wirausaha muda dalam bidang kuliner di Binong Tangerang yang ditandai dengan $\mathrm{H} 1$ dan adanya pengaruh yang signifikan antara variabel pengambilan risiko terhadap variabel perkembangan wirausaha muda dalam bidang kuliner di wilayah Binong Tangerang yang ditandai dengan $\mathrm{H} 2$.

Pada hipotesis pertama $(\mathrm{H} 1)$ dijelaskan secara sementara bahwa terdapat hubungan yang signifikan antara inovasi dengan perkembangan wirausaha. Pada bagian uji validitas dan uji reliabilitas, pada uji validitas sebelumnya, telah dibahas bahwa peneliti mengambil 10 responden dari total 50 responden, di mana 10 responden tersebut digunakan untuk menguji apakah masingmasing indikator dari variabel inovasi tersebut valid / layak untuk dilanjutkan atau tidak. Hasilnya menunjukkan bahwa dari total 10 indikator dari variabel tersebut, 2 tidak valid sehingga harus dibuang dan 8 lainnya sudah valid, yang artinya layak untuk dilanjutkan. Dan tentunya variabel inovasi sudah diuji reliabelnya karena sudah melebihi 0.6. Dan pada pengujian hipotesis pertama $(\mathrm{H} 1)$ berdasarkan hasil analisis data pada bagian hasil uji $t$ (Uji parsial) pada tabel 4.14 menunjukkan bahwa nilai signifikansi untuk variabel inovasi sebesar 0.163 yaitu lebih besar dari $\alpha=0.05$. Sedangkan kriteria untuk melihat apakah suatu hipotesis dari suatu variabel itu diterima atau ditolak adalah jika nilai signifikansinya $<0.05$ dinyatakan bahwa hipotesis tersebut diterima yang berarti bahwa variabel independen tersebut mempunyai pengaruh yang signifikan terhadap variabel dependen tersebut. Berdasarkan hasil analisis data beserta dengan pernyataan di atas, dapat disimpulkan bahwa tidak terdapat pengaruh yang signifikan antara variabel inovasi dengan variabel perkembangan wirausaha.

Bukti untuk mendukung penelitian ini adalah penelitian yang dilakukan oleh Serkan Bayraktaroglu dan Rana Ozen Kutanis dari Sakarya University pada tahun 2015 dengan judul "Testing Hypotheses Of Entrepreneurial Characteristics: A Cross Cultural Perspective", di mana pada penelitian ini, mereka meneliti pengaruh salah satu hipotesis dari enam hipotesis yang diteliti yaitu pengaruh inovasi terhadap 120 mahasiswa MBA di Sakarya University di Turki dan juga terhadap 120 mahasiswa MBA yang berada di salah satu universitas di Hong Kong dalam kecenderungan untuk berwirausaha. Di akhir penelitian mereka, diperoleh sebuah hipotesis bahwa variabel inovasi tidak berpengaruh terlalu signifikan terhadap kecenderungan berwirausaha, baik oleh mahasiswa di Turki maupun di Hong Kong. Jika dilihat dari segi metode penelitian, bisa disimpulkan bahwa asumsi analisis data pada uji t variabel inovasi tidak terpenuhi, dengan kata lain data tersebut menyimpang jauh daripada yang disyaratkan. Dan selain dari hasil analisis data, yang juga didukung dengan penelitian yang relevan yang dilakukan oleh para penelitian terdahulu oleh peneliti sebelumnya, peneliti memperoleh sebuah kesimpulan mengenai suatu hipotesis bahwa variabel inovasi tidak berpengaruh terlalu signifikan terhadap variabel perkembangan wirausaha muda dala menjalankan usaha kuliner di wilayah Binong Tangerang.

Pada hipotesis kedua $(\mathrm{H} 2)$ dijelaskan secara sementara bahwa terdapat hubungan yang signifikan antara pengambilan risiko dengan perkembangan wirausaha. Pada bagian uji validitas dan uji reliabilitas, pada uji validitas sebelumnya, telah dibahas bahwa peneliti mengambil 10 responden dari total 50 responden, di mana 10 responden tersebut digunakan untuk menguji apakah masingmasing indikator dari variabel pengambilan risiko tersebut valid / layak untuk dilanjutkan atau tidak. Hasilnya menunjukkan bahwa dari total 10 indikator dari variabel tersebut, 2 tidak valid sehingga harus dibuang dan 8 lainnya sudah valid, yang artinya layak untuk dilanjutkan. Dan tentunya variabel pengambilan risiko sudah diuji reliabelnya karena sudah melebihi 0.6. Dan pada pengujian hipotesis kedua $(\mathrm{H} 2)$ berdasarkan hasil analisis data pada bagian hasil uji t (Uji parsial) pada tabel 4.14 menunjukan bahwa nilai signifikansi untuk variabel pengambilan risiko sebesar 0.002 yaitu lebih kecil dari $\alpha=$ 0.05 . Sedangkan kriteria untuk melihat apakah suatu hipotesis dari suatu variabel itu diterima atau ditolak adalah jika nilai signifikansinya < 0.05 dinyatakan bahwa hipotesis tersebut diterima yang berarti bahwa variabel independen tersebut mempunyai pengaruh yang signifikan terhadap variabel dependen tersebut. Hal tersebut sejalan dengan penelitian yang dilakukan oleh Mohammad Behroozi (2012) yang berjudul Survey On University Role In Preparation Graduated Students In To Entrepreneurs universities 
Towards A Conceptual Framework: Iran's Perspective yang ditujukan untuk mengetahui bagaimana perspective Iran mengenai survei dari sebuah Universitas mengenai peran Universitas pengaruh edukasi dan karakteristik (Salah satunya variabel pengambilan risiko) dalam mempersiapkan mahasiswa yang baru lulus untuk menjadi seorang entrepreneur dalam mengembangkan usaha mereka. Dimana variabel dependennya adalah mempersiapkan mahasiswa yang baru lulus untuk menjadi seorang entrepreneur dalam mengembangkan usaha mereka, dan variabel independennya salah satunya adalah karakteristik di mana salah satu dari karakteristik tersebut adalah pengambilan risiko. Data dikumpulkan dari 3901 responden, di mana respondennya diantaranya adakah mahasiswa dan profesor dari Universitas Medical Sciences dan Universitas Persian Gulf di Kota Bushehr. Berdasarkan rumusan yang terkait dalam penelitian tersebut dan pengambilan sampel acak secara sistematis, 397 yang telah dipilih di mana didalamnya termasuk 201 perempuan dan 196 pria di antaranya ada 86 dosen dan 311 siswa. Skala Likert digunakan untuk mengukur efek akademik dari satu Universitas dalam mempersiapkan para lulusan bidang entrepreneur di mana semua itu menjadi salah satu faktor efektif dalam kelulusan bidang akademik terutama di bidang entrepeneurship yang harus diukur. Hasil yang didapat membuktikan terdapat hubungan yang positif antara variabel independen, yaitu salah satunya adalah variabel pengambilan risiko terhadap variabel dependen yaitu mempersiapkan mahasiswa yang baru lulus untuk menjadi seorang entrepreneur dalam mengembangkan usaha mereka.

Bukti lainnya untuk mendukung penelitian ini adalah sebuah penelitian yang dilakukan oleh Hatta (2014) yang berjudul Analisis Pengaruh Inovasi, Pengambilan Risiko, Otonomi, Dan Reaksi Proaktif Terhadap Kapabilitas Pemasaran UKM Kuliner Daerah Di JABODETABEK yang ditujukan untuk mengetahui pengaruh dari pengambilan risiko terhadap kapabilitas pemasaran UKM Kuliner Daerah di JABODETABEK yang merupakan kunci keberhasilan UKM di Indonesia. Di mana variabel dependennya salah satunya adalah kapabilitas pemasaran UKM Kuliner Daerah di JABODETABEK. Dalam hal ini kapabilitas merupakan kemampuan untuk mengembangkan usaha salah satunya dalam menjalankan UKM, sedangkan variabel independennya adalah pengambilan risiko. Pengumpulan data pada penelitian ini menggunakan instrumen kuesioner dengan metode survei. Metode pengambilan sampel yang digunakan adalah probability sampling dengan teknik simple random sampling. Populasi adalah seluruh restoran khas daerah yang berada di daerah JABODETABEK, sedangkan jumlah sampel yang terpilih adalah 200 restoran, yang masing-masing diwakili oleh responden pemilik atau pekerja senior di restoran tersebut. Instrumen peng-ukuran digunakan kuesioner dengan skala Likert dengan 5 (lima) skor penilaian yaitu $1=$ sangat tidak setuju, 2 = tidak setuju, $3=$ netral, $4=$ setuju dan $5=$ sangat setuju. Model yang digunakan dalam penelitian adalah model kausalitas atau hubungan sebab akibat, dalam bentuk persamaan SEM (Structural Equation Modelling). Pengolahan data dalam menemukan persamaan SEM, menggunakan paket program Lisrel versi 8.5. Profil responden penelitian dilakukan terhadap 200 restoran khas daerah di JABODETABEK. Pemilihan responden secara simple random. Responden kebanyakan berlokasi di Jakarta (82\%), sisanya berlokasi di Depok, Tangerang, Bogor, dan Bekasi. Kuesioner diisi oleh pemilik (25\%) dan manajer restoran (75\%). Kebanyakan responden adalah restoran khas Jawa (49\%), Sunda (15,5\%), Padang (12,5\%), Betawi $6 \%$ ), lainnya (17\%). Hasil yang didapat membuktikan terdapat hubungan yang positif antara variabel independen, yaitu pengambilan risiko terhadap variabel dependen yaitu kapabilitas pemasaran UKM Kuliner Daerah di JABODETABEK Dalam hal ini kapabilitas merupakan kemampuan untuk mengembangkan usaha salah satunya dalam menjalankan UKM. Jika dilihat dari segi metode penelitian, bisa disimpulkan bahwa asumsi analisis data pada $u j i \mathrm{t}$ variabel pengambilan risiko sudah terpenuhi, dengan kata lain data tersebut sudah sesuai dengan yang disyaratkan. Dan selain dari hasil analisis data, yang juga didukung dengan penelitian yang relevan yang dilakukan oleh para penelitian terdahulu oleh peneliti sebelumnya, peneliti memperoleh sebuah kesimpulan mengenai suatu hipotesis bahwa variabel pengambilan risiko berpengaruh secara signifikan terhadap variabel perkembangan wirausaha muda dalam menjalankan usaha kuliner di wilayah Binong Tangerang.

\subsection{Simpulan}

Berdasarkan hasil analisis data maka penulis membuat kesimpulan dari penelitian ini sebagai berikut :

1. Pada hipotesis pertama menunjukkan bahwa tidak terdapat pengaruh yang signifikan antara inovasi terhadap perkembangan wirausaha muda dalam 
bidang kuliner yang berada di wilayah Binong Tangerang.

2. Pada hipotesis kedua menunjukkan bahwa terdapat pengaruh yang signifikan antara pengambilan resiko terhadap perkembangan wirausaha muda dalam bidang kuliner yang berada di wilayah Binong Tangerang

\section{Daftar Pustaka}

[1] Bayraktaroglu. S, Kutanis. R.O. (2015). Testing Hypotheses Of Entrepreneurial Characteristics: A Cross Cultural Perspective. Sakarya University, Turkey.

[2] Behroozi. M. (2012). Survey on University Role in Preparation Graduated Students in to Entrepreneurs Universities Towards a Conceptual Framework: Iran's Perspective, Procedia-Social and Behavioral Sciences. 46, 2414-2418.

[3] Bustami, Bernadien, Nurlela, Sandra, Ferry. (2007). Mari Membangun Usaha Mandiri. Pedoman Praktis Bagi UKM. Penerbit: Graha Ilmu Yogyakarta.

[4] David and Cromie, S. (2008). Relation Marketing Entrepreneur and Bussines Performance. Journal SMEs: Marketing Entrepreneur, Vol. 4, No. 1.

[5] Dewi. R. S. (2013). Pengaruh Faktor Modal Psikologis, Karakteristik Entrepreneur, Inovasi, Manajemen Sumber Daya Manusia, Dan Karakteristik UKM Terhadap Perkembangan Usaha Pedagang Di Pasar Tradisional (Studi Kasus Pada Pedagang Sembako Dan Snack Di Pasar Peterongan). Jurnal Administrasi Bisnis, 2 (1).

[6] Djojosoedarso, S. (2003). Prinsip-Prinsip Manajemen Risiko dan Asuransi. Edisi Revisi. Jakarta: Salemba Empat.

[7] Hadiyati. (2010). Pemasaran Untuk UMKM (Teori dan Aplikasi). Edisi Pertama. Cetakan Pertama. Penerbit: Bayumedia Publishing, Malang

[8] Hatta, I. H. (2014). Analisis Pengaruh Inovasi, Pengambilan Risiko, Otonomi, Dan Reaksi Proaktif Terhadap Kapabilitas Pemasaran UKM Kuliner Daerah Di JABODETABEK. Jurnal manajemen Pemasaran, 8(2), 90-96

[9] Kasali, Rhenald., Nasution, Hakim Nasution,. , Purnomo, Boyke R., et. al. (2010). Modul Kewirausahaan Untuk Program Strata I. Penerbit: Hikmah

[10] Kearney. Claudine., Hisrich. Robert D. (2013). Managing Innovation And Entrepreneurship. Penerbit: ASA Bookstore
[11] Kotler, Philip. \& Gary Amstrong. (2006). Principles Of Marketing. New Jersey: Pearson Prentice Hall.

[12] Larsen, P. \& A. Lewis. (2007). How Award Winning SMEs Manage The Barriers to Innovation, Journal Creativity and Innovation Management, page: 141-151.

[13] Litbang "Kompas" / IWN, disarikan dari laman kementrian koperasi dan UKM, Kompas. Com, dan sumber lain.

[14]Malhotra, N. K. (2010). Marketing research. An applied orientation. New Jersey: Prentice Hall International Editions.

[15] Nur Shabrina Oktarilis. (2012). Pengaruh Faktor-Faktor Yang Dapat Memotivasi Mahasiswa Berkeinginan Wirausaha. Fakultas Ekonomi Jurusan Manajemen, Universitas Gunadarma

[16] Purwanti, Endang.2012 . Pengaruh Karakteristik Wirausaha, Modal Usaha, Strategi Pemasaran Terhadap Perkembangangan UMKM di Desa Dayaan dan Kalilondo Salatiga. STIE AMA Salatiga.Among Makarti, Vol.5 No.9, Juli 2012

[17] Pratiwi, Putri Eliza. (2013). Pengaruh Motivasi Terhadap Minat Berwirausaha Mahasiswa (Studi Kasus Pada Mahasiswa Program Studi Ekonomi Universitas Pendidikan Indonesia). Universitas Pendidikan Indonesia.

[18] Robbins, Stephen P. \& Coulter, Mary. (2010). Manajemen (Edisi Kesepuluh). Jakarta : Erlangga.

[19] Sugiyono, Dr., Prof., (2014). Metode Penelitian Kuantitatif Kualitatif dan R \& D. Bandung: Alfabeta.

[20] Sekaran,Uma \& Bougie, Roger.2016. Research Method for Business A Skill Building Approach. United Kingdom:John Wiley\&Sons Ltd.

[21] Tama, Angki adi. (2010). Analisis Faktorfaktor yang Memotivasi Mahasiswa Berkeinginan Menjadi Entrepreneur. Jurnal Universitas Diponogoro. 2(6). h. 20-32.

[22] Timmons, Jeffry A. (2008). New Venture Creation : Entrepreneurship For The 21st Century (Edisi 6). Penerbit: Andi, Yogyakarta

[23] Undang-Undang Republik Indonesia Nomor 18 Tahun 2002 Tentang Sistem Nasional Penelitian, Pengembangan, Dan Penerapan IImu Pengetahuan Dan Teknologi

[24] www.readersdigest.co.id/investasi-danbisnis/pentingnya+inovasi+dalam+bisnis 